\title{
Job Satisfaction, Stress and Coping Strategies in the Teaching Profession-What Do Teachers Say?
}

\author{
Einar M. Skaalvik ${ }^{1} \&$ Sidsel Skaalvik ${ }^{1}$ \\ ${ }^{1}$ Department of Education, Norwegian University of Science and Technology, Trondheim, Norway \\ Correspondence: Einar M. Skaalvik, Department of Education, Norwegian University of Science and \\ Technology, Trondheim, Norway. E-mail: einar.skaalvik@svt.ntnu.no
}

Received: October 14, 2014 Accepted: November 19, 2014 Online Published: February 26, 2015

doi:10.5539/ies.v8n3p181 URL: http://dx.doi.org/10.5539/ies.v8n3p181

\begin{abstract}
This study explored job satisfaction, work-related stress, consequences of stress, and coping strategies among Norwegian teachers. The study is based on qualitative interviews with 30 working teachers and four retired teachers. The respondents reported high job satisfaction but also severe stress and exhaustion. Teachers of different ages or at different stages in their careers reported the same sources of job satisfaction and stress. However, coping strategies and consequences differed with age among the respondents.
\end{abstract}

Keywords: teacher job satisfaction, teacher stress, coping strategies, consequences of stress

\section{Introduction}

International research shows that teaching is perceived as rewarding by most teachers but that many teachers also report a high degree of stress and symptoms of burnout (Johnson \& Birkeland, 2003; Neves de Jesus \& Lens, 2005; Stoeber \& Rennert, 2008). Research also reveals that teacher attrition (the departure of teachers from their teaching jobs) has become a global problem (Chang, 2009; Hong, 2010; Ingersoll, 2001). Furthermore, teacher research reveals that although teacher stress and teacher attrition are related to both teachers' life situations and personal characteristics, stress and attrition are also strongly related to teachers' working conditions (e.g., Day, Sammons, Stobard, Kington, \& Gu, 2007; E. Skaalvik \& S. Skaalvik, 2011a). For instance, excessive workload has been found to predict emotional exhaustion, motivation to leave the teaching profession, and actual teacher attrition (E. Skaalvik \& S. Skaalvik, 2011a; Smithers \& Robinson, 2008), whereas supportive school environments are positively related to motivation to stay in the teaching profession (E. Skaalvik \& S. Skaalvik, 2011a; Weiss, 1999).

Because the attrition rate follows a U-shaped curve, with the highest attrition rates observed early and late in teachers' careers (Borman \& Dowling, 2008; Rinke, 2007), it is important to gain more insight into how teachers experience their work and their working conditions at different stages of their careers. Also, most research on teacher job satisfaction, stress, and motivation to leave the teaching profession are based on survey methodologies, whereas little research is based on open interviews with larger samples of teachers or trainee teachers (but see Johnson \& Birkeland, 2003; Mtika \& Gates, 2011; Younge, Brindley, Pedder, \& Hagger, 2004). In the present study, the researchers therefore conducted open-ended interviews of Norwegian teachers at different stages in their careers focusing on school-related sources of job satisfaction and stress.

\subsection{Job Satisfaction and Motivation to Stay in or to Leave the Profession}

In this study job satisfaction is conceptualized as the positive or negative evaluative judgments that people make about their jobs (see Weiss, 2002). Dinham and Scott (1998) classified the sources of job satisfaction and dissatisfaction into three domains: (a) intrinsic rewards of teaching, (b) factors extrinsic to the school, and (c) school-based factors. The intrinsic rewards of teaching concerns the actual work of teaching, working with the students, and seeing students learn and develop. Empirical studies verify that job satisfaction for many teachers is related to working with young people and to the actual work of teaching (Guarino, Santibañez, \& Daley, 2006; Scott, Stone, \& Dinham, 2001; Watt \& Richardson, 2008).

A number of school-based factors have also been shown to be related to teacher job satisfaction. Teacher autonomy has been shown to be associated with higher levels of job satisfaction (Guarino, Santibañez, \& Daley, 2006; Koustelios, Karabstzaki, \& Kousteliou, 2004; E. Skaalvik \& S. Skaalvik, 2009; Zembylas \& 
Papanastasiou, 2006). Supportive school environments and positive social relations with parents, colleagues, and the school leadership are also predictive of teachers' job satisfaction and motivation to stay in the profession whereas time pressure and discipline problems are predictive of lower levels of job satisfaction (Day, Sammons, Stobard et al., 2007; Johnson \& Birkeland, 2003; Scheopner, 2010; Weiss, 1999). E. Skaalvik and S. Skaalvik (2011a, b) also revealed that value consonance, the degree to which teachers feel that they share the prevailing norms and values at the school where they are teaching, was positively related to teachers' job satisfaction and feeling of belonging. Several studies also reveal that teacher self-efficacy is associated with higher levels of job satisfaction (Johnson \& Birkeland, 2003; Klassen \& Chiu, 2010).

\subsection{Stress and Burnout}

Teacher stress has been defined in different ways. Otto (1986) conceptualized work-related stress as resulting from a mismatch or a lack of fit between external and internal job demands and external and internal resources whereas Kyriacou (2001) defined stress as the experience of negative or unpleasant emotions resulting from aspects of the work. Thus, teachers may experience stress if the job demands do not fit their perceived capacity to meet the demands or their educational values. Teachers' occupational stress is associated with several contextual factors such as time pressure, discipline problems, lack of resources, lack of professional recognition, lack of support and the diversity of tasks required (Kokkinos, 2007).

Burnout is often described as a syndrome of emotional exhaustion, depersonalization, and reduced personal accomplishment (Maslach \& Jackson, 1981; Maslach, Jackson, \& Leiter, 1996) and is conceptualized as resulting from long-term occupational stress (Jennett, Harris, \& Meisbov, 2003). Burnout develops gradually and is described as the end stage of a chain of reactions (Peeters \& Rutte, 2005). The development of burnout most often starts with a feeling of emotional exhaustion, which is regarded as the key aspect of the syndrome. Both measures of burnout and emotional exhaustion has been shown to be related to teachers' self-efficacy, motivation, job satisfaction, well-being, and intentions to leave the teaching profession (Hakanen, Bakker, \& Schaufeli, 2006; Leung \& Lee, 2006; Schaufeli \& Salanova, 2007; E. Skaalvik \& S. Skaalvik, 2009, 2010, 2011a; Tang, Au, Schwarzer, \& Schmitz, 2001).

A number a studies show that teachers experience an increased workload and a hectic workday (Hargreaves, 2003; Johnson \& Birkeland, 2003; Lindqvist \& Nordänger, 2006). E. Skaalvik and S. Skaalvik (2011a) refer to the combination of work overload and hectic workdays with little time for rest and recovery as "time pressure". Different measures of time pressure have been found to predict teacher stress (Farber, 1991; Pithers \& Soden, 1998) and both emotional exhaustion and burnout (Hakanen, Bakker, \& Schaufeli, 2006; Kokkinos, 2007; Lee \& Ashforth, 1996; E. Skaalvik \& S. Skaalvik, 2011a). A number of studies also reveal that discipline problems are related to teacher burnout (Hakanen et al., 2006; Kokkinos, 2007; E. Skaalvik \& S. Skaalvik, 2011a).

A positive social climate at school, including social support and positive relations with colleagues, parents, and students, has been shown to be negatively related to teacher burnout (Hakanen et al., 2006; Leung \& Lee, 2006). In a series of studies, E. Skaalvik and E. Skaalvik $(2009,2014)$ found that teacher autonomy predicted higher levels of engagement and job satisfaction and lower levels of burnout.

\subsection{The Present Study}

Most of the previous research on teacher job satisfaction, stress, and burnout and how these responses relate to teachers' working conditions, well-being, and motivation are based on survey methodology. In the present study, open-ended interviews with 30 Norwegian elementary and middle school teachers and four former teachers on early retirement were therefore conducted. The study was designed to shed light on the following research questions:

(1) How did the teachers describe their job satisfaction and its sources of job satisfaction?

(2) What job-related challenges and strains did the teachers experience?

(3) What consequences of work-related stress did the teachers report?

(4) What strategies did the teachers use to cope with work-related stress?

\section{Method}

\subsection{Participants}

The participants in this study were 30 teachers in elementary and middle schools and four retired teachers, all of whom taught in one region in Norway. Seven schools from a middle sized city and three schools from the district surrounding the city were randomly selected. Three teachers were selected from each of these schools, one young teacher (27-34 years), one middle aged teacher (35-50 years), and one senior teacher (51-63 years). The 
sample was built gradually and purposively in order to attain variation in age, sex, and type of school (elementary and middle schools). In the young group, there were three female and seven male teachers, whereas in both the middle-aged and senior groups, there were seven female and three male teachers in each group. Eighteen of the participants taught in elementary schools, whereas 12 of the participants taught in middle schools. The teachers were asked if they wanted to participate in the study and told that they could withdraw from the study at any time before, during, or after the interview. No teachers chose to withdraw.

To find teachers on early retirement, the working teachers were asked if they knew teachers that recently had left their teaching position before the retirement age of 67 years. Four former teachers were chosen through this process, two teachers who had left school with early retirement at the age of 62 (the retirement age is 67), and two teachers who had retired after two years with disability pensions. The four pensioned teachers were one male and three females. Three of them had taught in elementary school, whereas one had taught in middle school.

\subsection{The Interviews}

Interviews in the form of semi-structured dialogues were conducted with each respondent. All interviews started with asking the respondents what their immediate thoughts about working as a teacher were. Next, follow-up questions such as the following were asked: "Can you tell me more about that?" (i.e., the topics of the respondents' responses), "Do you have any examples illustrating that?", and "Can you elaborate on that?" Then, the interviewer asked open-ended questions about job satisfaction, sources of satisfaction and dissatisfaction, challenges and strains in the profession, sources of challenges and strains, and reactions to and consequences of challenges and strains.

The individual interviews lasted between 60 and 90 minutes and were conducted in an office or empty classroom chosen by the respondent. Before the interview, the teachers were informed that participation was voluntary, that they could withdraw from the interview at any time, and that they were free not to answer questions if they felt uncomfortable. The interviews were taped and transcribed.

\subsection{Analysis and Presentation}

The transcripts were read several times searching for topics and thematic patterns. All statements about (a) job satisfaction, (b) challenges and strains, (c) consequences of strains, and (d) strategies to cope with stains were first sorted into four groups of statements. The statements in each of these groups were then analyzed to find reasons for job satisfaction, challenges and strains, and different types of consequences and strategies. The reasons for job satisfaction and stress as well as the types of consequences and strategies were then narrowed down to fewer categories which encompassed similar meanings or thought processes (Creswell, 2005).

\section{Findings}

\subsection{Job Satisfaction}

All 34 informants responded to the introductory question about immediate thoughts about working as a teacher by emphasizing high job satisfaction. For instance, one senior teacher said: "I have made the right career choice. Being 63 years, I still enjoy every day, and I am looking forward to the next school year" (female teacher, 63 years).

Our analysis resulted in four main categories of sources of job satisfaction:

- Working with children.

- Variation and unpredictability.

- Cooperation and teamwork.

- Autonomy.

\subsubsection{Working with Children}

All participating teachers emphasized the enjoyment of teaching and working with children, and that it was a meaningful job. These responses included comments about working with the children, seeing them learn and develop, and helping them both socially and in their school learning. Several teachers said that working with the children and seeing them learn and develop gave them energy. Twenty-one of the teachers also emphasized the actual process of teaching and conveying subject knowledge to the students as one source of job satisfaction. These teachers also related job satisfaction to mastery experiences and a feeling of competence. They clearly related job satisfaction and enjoyment of teaching to succeeding with their teaching and their interaction with the students. 
"I have always enjoyed working with children, and that is the reason that I am still teaching" (male teacher, 32 years); "I feel successful when the students get engaged and learn what I have been teaching. I often have that feeling" (female teacher, 42 years); "I like conveying knowledge. What drives me as a teacher is the possibility to convey knowledge to the students" (female teacher, 58 years);

\subsubsection{Variation and Unpredictability}

Seventeen of the teachers also pointed at the variation and unpredictability of teaching as sources of job satisfaction. They said that no days were alike and that each day brought new challenges. Some teachers said that not knowing what the day would bring was a source of excitement.

"No days are alike because there are always new challenges. It is a good feeling not to know what the day will bring" (male teacher, 30 years); "I appreciate that every day brings something new. After 30 years as a teacher, I still have butterflies in my stomach when I am on my way to the school. And that is wonderful-that it is not so predictable" (male teacher, 53 years).

\subsubsection{Cooperation and Teamwork}

In Norwegian schools, a team of teachers often share responsibility for all students at a certain grade level. Teachers therefore have to cooperate in both planning and conducting the instruction, including the organization of teaching at the level where they are teaching. Fifteen of the teachers said that cooperating with colleagues in teams was one source of enjoyment, learning, and job satisfaction. In particular, the youngest teachers noted that teachers supported each other and learned from each other. They also emphasized the advantage of teachers having different strengths, both because they could learn for each other and because the students had different teachers to ask for help.

"We are four teachers sharing responsibility for the students at our grade level. We have different strengths, which increases our ability to meet different student needs" (male teacher, 34 years); "The teachers on my team support each other. We divide the responsibilities, and we back each other up when it is needed" (female teacher 51 years).

\subsubsection{Autonomy}

Ten of the teachers explicitly emphasized autonomy and flexibility as major sources of job satisfaction. They described the teaching role as one of responsibility and independence. They appreciated the opportunity to choose how to work with their students. For some teachers, autonomy also included flexibility, the opportunity to choose where and when to prepare for teaching - for instance, at home.

"Because I have flexible working hours [except for the actual teaching], I can do my work thoroughly, particularly the preparation for teaching" (male teacher, 29 years). "I appreciate the flexibility I have in my work. I enjoy challenges that I can handle, but that requires that I am free to do what I believe will work the best" (male teacher, 52 years);

All of the reasons for job satisfaction were emphasized by both male and female teachers and by teachers in different age groups. Therefore, it was not possible to find differences in reasons for job satisfaction based on gender or age.

\subsection{Challenges and Stress}

In spite of the high job satisfaction reported, all 34 respondents were also occupied by challenges and stress in the teaching profession. The teachers' statements about strains were classified into six categories:

- Workload and time pressure.

- $\quad$ Adapting teaching to students' needs.

- Disruptive student behavior.

- Value conflicts and lack of autonomy.

- Teamwork.

- Lack of status.

\subsubsection{Workload and Time Pressure}

The majority of teachers $(n=29)$ found that workload and the time pressure were extremely stressing. They emphasized that the working days at school were hectic and provided little time for rest and relaxation. Too many tasks were to be conducted in too little time. For instance, they were often interrupted when trying to concentrate on one activity (e.g., preparing for teaching). In addition to teaching and preparation for teaching, the 
respondents referred to a number of tasks and activities - for instance, staff and team meetings, copying learning material, contact with parents via e-mail and telephone, meetings with parents, documentation of meetings with parents, documentation of dialogues with students in the form of notes or summaries, and communication with the special education cervices about students with problems. Which of these tasks took the most time differed from school to school, but the accumulation of these tasks and activities was common to most teachers.

"What I dislike about working as a teacher is the time pressure. It is enormous" (male teacher, 30 years); "Intense is the word I would use to describe a day at school. Very intense. And loaded with lots of details" (female teacher, 57 years).

\subsubsection{Adapting Teaching to Students' Needs}

Inclusive education is a political goal in Norwegian schools. As a consequence, there are few special schools or special classes left in Norway, and teachers in ordinary school are responsible for adapting their teaching to individual students' needs in classes with a large diversity in students' abilities. A large group of teachers $(n=24)$ noted this responsibility as a major source of stress. They felt that they were not able to meet this responsibility, partly because they did not have the time to address all students' needs and partly because they did not have the competency to do so.

"I am falling short when it comes to students with severe disabilities. In our grade level we have one student with Asperger's disorder and several students with dyslexia and none of us have the competency to teach these students (male teacher, 33 years); "The greatest challenge is the diversity in the student group. I am falling short when it comes to handling this diversity" (female teacher, 62 years).

\subsubsection{Disruptive Student Behavior}

Twenty-five of the respondents elaborated on student misbehavior or discipline problems as one source of stress. Several teachers said that student misbehavior was the most serious problem in school. They explained that disruptive behavior made the teaching difficult to conduct. Teachers who managed to maintain discipline also said that doing so and being alert was extremely energy intensive.

"We use $80 \%$ of the time on five students with behavioral problems. We use an extremely amount of energy on these students" (male student 28 years);"I am falling short when it comes to students who have concentration problems, students with disruptive behavior, and students who run off or walk about in the landscape. I feel unsuccessful when this happens, which is quite often" (female teacher, 59 years).

\subsubsection{Value Conflicts and Lack of Autonomy}

Seventeen of the respondents were concerned that the prevailing educational goals and values at school were not compatible with their own educational values and beliefs. They explained that this problem partly was due to the national curriculum and partly due to goals and values emphasized at the school or the team they were working with. As a result, they felt that there was a mismatch between their own educational goals and values and the educational practice that they felt they had to conduct. The value conflicts were seen as a result of lack of autonomy and lack of faculty influence.

"The school principal expects everybody to work the same way" (male teacher, 33 years); "I feel that the values we stood for are not important in school today. What are valued today are test results. We no longer have the opportunity to teach according to our beliefs" (female teacher, 51 years); "The new management model means that we [the teachers] no longer have any influence. That is true, for instance, for the use of the school resources" (female teacher, 52 years).

\subsubsection{Teamwork}

As noted above, 15 of the teachers said that cooperating with colleagues in teams was a source of enjoyment and job satisfaction. However, teamwork may also be a challenge and a source of stress. Sixteen of the respondents talked about teamwork as a source of stress. They said that teamwork often led to disagreements and even open quarrels in front of their students. Because teachers did not choose their teammates, some team members had significantly different goals, values, and ways of handling students.

"Working in a team may be a strength, but it is also vulnerable. When it does not work, one should think more of the students because they suffer when teachers do not agree and argue against each other in front of the students" (male teacher, 32 years).

\subsubsection{Lack of Status}

Sixteen of the respondents noted lack of status of the teaching profession as one source of dissatisfaction and 
stress. They particularly pointed at critical and negative references to teachers and schools in the media. Some teachers also referred to a feeling that they had low status among the parents. This feeling turned mandatory meetings with parents into a stress factor.

"When I read about schools in the newspapers and on the net, I get the impression that we are still a group that they are putting a slur on" (male teacher, 42 years).

Like the reasons for job satisfaction, all of the challenges and strains were emphasized by both male and female teachers and by teachers in different age groups. Thus, it was not possible to identify differences in reasons for challenges and strains based on gender or age.

\subsection{Consequences of Workload and Strains}

According to the respondents in this study, the high degree of stress in the teaching profession had serious consequences. They talked about stress and the consequences of stress in the same breath. The responses may be classified into three large categories of consequences:

- Exhaustion and psychosomatic symptoms.

- $\quad$ Reduced accomplishment and loss of self-efficacy.

- $\quad$ Negative affect and loss of self-esteem.

\subsubsection{Exhaustion and Psychosomatic Symptoms}

Physical and emotional exhaustion are theoretically distinct from psychosomatic symptoms. The reason for placing them in the same category is that several teachers talked about these consequences in the same vein. Thirty-two of the 34 informants reported experiences of exhaustion and 26 of these also emphasized psychosomatic responses. They talked about exhaustion in terms of lack of energy, which again had different consequences. Work-related consequences included a reduced ability to prepare for teaching, concentration problems, and forgetfulness. Personal and social consequences included not being able to do much after working hours, sacrificing their friends and their social lives, and neglecting their families. Health related consequences included sleeping problems, neck and back pain and headaches. The responses also indicated a tendency that younger teachers were able to recover during vacations whereas this was not the case for middle aged and senior teachers.

"Last year, I was really scared. I could not sleep, I could not think, and I was lying in bed shaking. I got dizzy when trying get up" (female teacher, 27 years); "Last year I was exhausted. I did not have the energy to do anything in the afternoon or at night. I felt physically exhausted after six hours of teaching, and this lasted for a whole school year" (male teacher, 31 years); "I had a hard period last autumn, and I had no energy when school started after the summer holiday" (female teacher, 40 years); "It [being exhausted] did not deprive me of sleep at night, but I was going to sleep with a headache and waking up with a headache. My family suffered from this too" (female teacher, 45 years); "I was exhausted and did not sleep well. I also got a rapid heartbeat, headaches, and a stiff neck. I still have it. If I am stressed, I get back the stiff neck" (retired female teacher 1).

\subsubsection{Reduced Accomplishment and Loss of Self-Efficacy}

Eight of the respondents reported a loss of self-efficacy and a feeling of reduced accomplishment. Six of these teachers were past 50 years of age, and said that they no longer were able to manage the increased workload or to keep discipline in the classroom. They felt a loss of control, and two of the teachers said that loss of control led to a lack of inspiration.

"I have a feeling of not being able to cope with the situation, and I am afraid of not doing a good job. I worry about all the tasks that I have ahead of me" (female teacher, 40 years); "My attention was on negative things - situations that I should have handled better-and that made things worse. I had a strong feeling of losing control" (retired male teacher); "When I felt that I did not master the job as well as I used to do, then of course you get a lower self-perception, because the job is such a large part of yourself. When you do not manage, you get a lower self-picture" (retired female teacher 2).

Both emotional exhaustion and reduced accomplishment are traditionally viewed as dimensions of burnout. A third dimension of burnout is depersonalization. One senior teacher and two of the retired teachers reported thoughts and feelings indicating an incipient depersonalization.

"Negative feelings towards the pupils were there. I had to use a lot of energy pretending that this problem did not exist because one does not want to expose negative feelings" (retired female teacher 3 ). 


\subsubsection{Negative Affect and Loss of Self-Esteem}

Nine of the respondents reported negative affect and loss of self-esteem as consequences of stress. They reported negative feelings such as anger, frustration, and guilty conscience related to students with special needs.

"I was so frustrated. I snapped at the pupils and was not nice at all. I had been on my uppers for a long period" (female teacher, 58 years);"I experience stress at work when I have too much to do. I can feel it in my heart, and I get hotheaded. I get hot-headed" (female teacher, 51 years).

Three of the retired teachers reported a serious loss of self-esteem, partly because they felt that they had not been able to work until they reached retirement age at 67 . They felt that they had failed in their work and that they had left the profession with little honor.

"I feel that I have lost face. I do not want any other teacher to leave the position this way. I feel that the way I left the position cast a shadow [over me]. ... I used to be outdoors, and I exercised a lot. But I have lost the motivation for that too. I have symptoms of what you may call depression. That is the reason that I left the teaching profession. I try to avoid meeting former colleagues, pupils or parents" (male teacher with early retirement); "I hope the soreness will fade away with time. But I do not think it will disappear completely. I think I always will think back on my professional life and how it ended" (female retired teacher who left school with disability pension).

\subsection{Strategies}

The strategies that the teachers reported for coping with challenges and strains seemed to vary with age among the informants. Strategies are therefore reported separately for the three age groups.

\subsubsection{Young Teachers (27-34 Years)}

The primary strategy reported by all of the ten teachers in the youngest group was to work hard to manage everything required of them and to be well prepared for their teaching. They had high ambitions for their teaching, and being well prepared was a common theme among the youngest teachers. One of the teachers said:

"When I am at work everything stands or falls on me. In a way, every day is an examination. If I am not well prepared, it reflects upon me. The two first years [as a teacher], I thought I could manage everything. I worked and worked and worked, at night, in the weekends and during the holidays" (female teacher, 27 years).

Most young teachers also avoided seeking sick leave. They emphasized that being on sick leave would hurt both their pupils and their colleagues. This thinking was partly due to a school policy of assigning the teacher team the responsibility of teaching these classes instead of using substitute teachers. Another consequence of the hard work was that the youngest teachers had to sacrifice their social lives. One teacher who had experienced severe exhaustion said:

"I had to quit everything that was not work-related. I just had to stop making appointments after working hours" (female teacher, 28 years).

The extreme amount of work that the youngest teachers reported is probably an important reason that even the youngest teachers experienced severe levels of exhaustion. Two of the youngest teachers said that this strategy did not work in the long run. They ended up feeling extremely exhausted and not being able to work at night and in the weekends. For these two younger teachers, the "working-hard-strategy" morphed into a "lower-the ambition-strategy". They tried to prepare for their teaching during school hours and just relax when they came home from school.

"I was so tired that I chose to protect myself as much as I could. Instead of preparing for my teaching, when I came home from school I just sat down. I chose that solution instead of asking for sick leave because I would feel that as defeat" (male teacher, 29 years).

One, but only one, of the youngest teachers said that he tried to recover by exercising. He used jogging and hiking to try to loosen the musculature.

\subsubsection{Middle Aged Teachers (35-50 Years)}

The middle-aged teachers also reported high ambitions and working long hours to prepare for their classes. However, whereas the youngest group of teachers avoided sick leave, six of the ten teachers in the middle-aged group used sick leave as a self-protective strategy. These teachers had reached a point where weekends and vacations were not sufficient to recover. When they felt that they were on the edge, they actively sought out or asked their doctors for sick leave for a short period of time, normally one to three weeks. 
"When I feel exhaustion because of the workload, I have to take a break [sick leave] of a week or two. When I notice that I am not responding adequately and it lies heavily on my conscience, then I say to myself that I may as well stay away from work" (male teacher, 36 years).

Two of the teachers in this group were also on a long-term but part-time $(20 \%)$ sick leave at the time when they were interviewed.

The middle-aged teachers also reported a growing motivation to leave the teaching profession, either permanently or for a period of time. This motivation manifested itself in different ways. Two of the teachers in this group said that they often thought about leaving the profession, and three of the teachers had taken a leave of absence to try other occupations but then returned to teaching after one or two years.

Four of the teachers in this age group tried to reduce the workload by reducing the teaching hours. Two of these teachers reduced their employment percentages to $80 \%$, and two teachers had $20 \%$ disability pensions. The former of these groups lost $20 \%$ of their income, whereas the latter group experienced minor reductions in income.

\subsubsection{Senior Teachers (51-63 Years)}

Four of the ten senior teachers still had high ambitions for their teaching. They actively used short-term sick leave (a week or two) as a strategy to escape from the stress and workload. Two of these teachers had also recently taken long-term sick leave due to stress and exhaustion. Following long-term sick leave, one teacher reduced her employment to $80 \%$ to be able to cope with the challenges whereas the one teacher was granted a $20 \%$ disability pension. The latter of these teachers said:

"The workload is too heavy when you have a fulltime position as a teacher. The demands are enormous, and I simply get too tired. I may not be burnt out, but I feel that I am worn out. After being granted a $20 \%$ disability pension and beginning to work $80 \%$, I feel more able to do the job properly. I no longer have the feeling that I do not know whether I am coming or going" (female teacher, 57 years).

Six of the senior teachers lowered their ambitions and reduced the amount of time they used to prepare their teaching. They reported that they either exercised or relaxed after work as a day-to-day strategy for reducing stress and exhaustion. Three of the teachers said that they both exercised on a regular basis and made sure that they got enough sleep, whereas three of the senior teachers chose to relax on the sofa and do as little as possible after school hours.

"I exercise to maintain my physical and mental health. That is very important. I also see that I get enough sleep" (female teacher, 61 years); "After a long day at school, I am extremely tired. When I get home, I lay down on the sofa to recover. It helps. The next day I am OK again" (female teacher, 62 years).

Although one of the teachers cited above said that relaxing on the sofa helped and that she felt fine the next day, other teachers said that they often started the school day feeling exhausted.

\section{Discussion}

All teachers participating in this study reported high job satisfaction. Nevertheless, supporting international research (e.g., Stoeber \& Rennert, 2008), all teachers also experienced a high degree of stress and many teachers showed severe physical and emotional exhaustion. According to the teachers, their primary source of job satisfaction was working with children, the actual process of teaching, and seeing their pupils learn and develop. Thus, job satisfaction was primarily related to the intrinsic rewards of teaching (see Dinham \& Scott, 1998), whereas stress was related to a number of school-based factors. These results reveal a serious problem related to teacher motivation, well-being, and therefore, the quality of education. However, it also shows opportunities for developing high-quality education because high-quality education requires teachers driven by the intrinsic motivation to teach.

\subsection{Sources of Stress}

The teachers experienced a number of causes of stress in their work. Each of six school-based sources of stress was reported by half or more than half of the teachers. This finding indicates that many teachers experience an accumulation of sources of stress, which may explain the high level of physical and emotional exhaustion. In an attempt to reduce the amount of stress among teachers, one therefore needs to consider the entirety of teachers' working conditions.

It is particularly important to note that, in accordance with international research, this study showed that teachers experience high workload and a severe time pressure at school. Several teachers said they were worn out at the 
end of the school day. This finding has clear practical implications. Most importantly, the workload on teachers has to be reduced, particularly the number of meetings, paperwork and documentation. Secondly, the findings strongly indicate that teachers need flexibility regarding where and when to prepare for teaching. For instance, the interviews indicate that many teachers need a break between teaching and preparation for teaching. This has important implications for an ongoing discussion in Norwegian school concerning the time that the teachers should be obligated to be present at school before and after the teaching hours.

Two of the sources of stress that were found in this study are given little attention in prior research: lack of value consonance and the adaption of teaching to individual students' needs. Value consonance, the degree to which teachers feel that they share the prevailing norms and values at the school where they teach, has in a couple of studies been shown to be relate positively to teachers' job satisfaction and feeling of belonging (E. Skaalvik \& S. Skaalvik, 2011a,b). Teaching is typically driven by values, ethical motives or intrinsic motivation (Sahlberg, 2010). Therefore, value consonance, which may be perceived as a dimension of the person-environment fit (Kristof, 1996), may be particularly important in the teaching profession. Lack of value consonance seems to be caused partly by the increasing dependency of the individual teacher on the teacher team and partly by an increasing tendency for micromanagement at schools. Collegial discussions of the goals and values of education are therefore necessary to create a collective culture at school.

The other source of stress that is not previously emphasized in previous research is the requirement that teachers should adapt their teaching to individual student' needs. This result should be interpreted in light of the Norwegian context. The ideal of inclusive education has been strongly emphasized in Norway, and practically all students are now enrolled in their home school. As a consequence, the diversity of cognitive and physical abilities within classes has become much wider. However, this change has not been accompanied by sufficient resources to handle this diversity.

The causes of stress emphasized by the teachers are partly interrelated. For instance, workload and time pressure most likely increase because of disruptive student behavior, conflicts in teacher teams, and the inclusive school policy not being accompanied by sufficient resources. Additionally, value conflict (the lack of value consonance) probably increases as a function of the stronger emphasis on teamwork and decreasing teacher autonomy. When teachers work in teams, they have to sacrifice part of their individual autonomy. That may be frustrating if teachers are not able to reach agreements about educational goals and values. Teamwork therefore requires constructive discussions about goals, norms, and values, both in teacher collegiums and in teacher teams.

\subsection{Consequences of Stress and Coping Strategies}

This study indicates that the perceived sources of job satisfaction and stress are the same for teachers regardless of age and experience. However, the consequences of stress and the coping strategies seem to change with age. The youngest teachers experience a heavy workload. Additionally, they have high ambitions for their teaching. Their main strategy is to work hard and at late hours to be as well prepared to teach as possible. They report being tired and exhausted, but at this age, they are able to recover during weekends and vacations, although some of the young teachers also work through the weekends. We should note that in this project, we reached only the young teachers who were still teaching. We do not know how many had left the teaching profession.

Teachers in the middle-aged group still had high ambitions and worked long hours. However, in this age group, the weekends and the vacations were not sufficient for recovery, and teachers reported severe exhaustion and psychosomatic reactions. Whereas the younger teachers avoided sick leave, the middle-aged teachers started using sick leave as a coping strategy to get short breaks from work. Some teachers in this group also began thinking about reducing their employment or asking for partial disability pensions.

The teachers in the senior group were no longer able to work the long hours that the heavy workload required. Some of the senior teachers responded by lowering their ambitions and working fewer hours at home to prepare to teach. After school hours, they used more time to exercise or relax. Nevertheless, they reported strong indications of exhaustion and even symptoms of burnout. In addition to reducing the amount of work done to prepare to teach, they also used sick leave as a survival strategy. Other senior teachers were not able or willing to lower their ambitions. However, they were no longer able to work long hours preparing their teaching and therefore were not able to meet their own expectations for their teaching. A reasonable interpretation is that this condition resulted in severe exhaustion and repeated periods of sick leave. Eventually, some teachers in this group had to reduce their employment, by accepting either a lower salary or by partial-disability pensions. The end result for some senior teachers is illustrated by the four teachers who had left the profession through early retirement or disability pensions after long periods of sick leave, resulting in depressed mood and lower self-esteem. 


\subsection{Conclusions and Limitations}

Both the workload and the accumulation of numerous sources of stress have a number of maladaptive consequences. Important consequences for a number of the teachers were physical and emotional exhaustion, the sacrifice of social lives, increasing instances of sick leave, the reduction of teachers' employment with economic consequences for the individual teachers, and early retirement, with disability pension for some teachers.

It should be noted that this study does not show consequences for the quality of teaching and the students' learning, which is an important task for future research. A reasonable assumption is that teachers who are exhausted, who do not share the goals and values of the school, who have to use teaching methods that they do not feel comfortable, or who are motivated to leave the teaching profession may not be as good teachers as they might have been. Possible consequences may be these teachers show less patience, are less willing to change their teaching practices, spend less time preparing for teaching, and are less sensitive to students' needs. However, these reflections need to be systematically investigated in future research. We therefore call for research studying the interaction between school level policy, teachers' reactions and student motivation, study behavior, and learning outcome.

Some limitations of this study should be noted. Although 34 teachers is a large sample for a qualitative study, it is not a random sample. Similar studies building on open-ended interviews are needed both in different cultures and at different grade levels. Another limitation is that the citations represent translations from Norwegian and nuances may be lost during the translation into English.

\section{References}

Borman, G. D., \& Dowling, N. M. (2008). Teacher attrition and retention: A meta-analytic and narrative review of the research. Review of Educational Research, 78, 367-409. http://dx.doi.org/10.3102/0034654308321455

Chang, M-L. (2009). An appraisal perspective of teacher burnout: Examining the emotional work of teachers. Educational Psychology Review, 21, 193-218. http://dx.doi.org/10.3102/0034654308321455

Creswell, J. W. (2005). Educational research: Planning, conducting, and evaluating quantitative and qualitative research. New Jersey: Pearson.

Day, C., Sammons, P., Stobard, G., Kington, A., \& Gu, Q. (2007). Teachers matter: Connecting work, lives and effectiveness. Berkshire, England: Open University Press.

Deci, E. L., \& Ryan, R. M. (2000). The "what" and "why" of goal pursuits: Human needs and the self-determination of behavior. Psychological Inquery, 11, 227-268. http://dx.doi.org/10.1207/S15327965PLI1104_01

Dinham, S., \& Scott, C. (1998). A three domain model of teacher and school executive career satisfaction. Journal of Educational Administration, 36, 362-378. http://dx.doi.org/10.1016/j.edurev.2010.03.001

Farber, B. A. (1991). Chrisis in education: Stress and burnout in the American teacher. San Fransisco, Ca: Jossey-Bass.

Fokkens-Bruinsma, M., \& Canrinus, E. T. (2014). Motivation for becoming a teacher and engagement with the profession: Evidence from different contexts. International Journal of Educational Research, 65, 65-74. http://dx.doi.org/10.1016/j.jer.2013.09.012

Guarino, C. M., Santibañez, L., \& Daley, G. A. (2006). Teacher recruitment and retention: A review of the recent empirical literature. Review of Educational Research, 76, 173-208. http://dx.doi.org/10.3102/00346543076002173

Hakanen, J. J., Bakker, A. B., \& Schaufeli, W. B. (2006). Burnout and work engagement among teachers. Journal of School Psychology, 43, 495-513. http://dx.doi.org/10.1016/j.jsp.2005.11.001

Hargreaves, A. (2003). Teaching in the knowledge society: Education in the age of insecurity. Milton Keynes: Open University Press.

Hong, J. Y. (2010). Pre-service and beginning teachers' professional identity and its relation to dropping out of the profession. Teaching and Teacher Education, 26, 1530-1543. http://dx.doi.org/10.1016/j.tate.2010.06.003

Ingersoll, R. M. (2001). Teacher turnover and teacher shortages: An organizational analysis. American Educational Research Journal, 38, 499-534. http://dx.doi.org/10.3102/00028312038003499 
Jennett, H. K., Harris, S. L., \& Mesibov, G. B. (2003). Commitment to philosophy, teacher efficacy, and burnout among teachers of children with autism. Journal of Autism and Developmental Disorders, 33, 583-593. http://dx.doi.org/10.1023/B:JADD.0000005996.19417.57

Johnson, S. M., \& Birkeland, S. E. (2003). Pursuing a "sense of success": New teachers explain their career decisions. American Educational Research Journal, 40, 581-617. http://dx.doi.org/10.3102/00028312040003581

Klassen, R. M., \& Chiu, M. M. (2010). Effects on teachers' self-efficacy and job satisfaction: Teacher gender, years of experience, and job stress. Journal of Educational Psychology, 102, 741-756. http://dx.doi.org/10.1037/a0019237

Kokkinos, C. M. (2007). Job stressors, personality and burnout in primary school teachers. British Journal of Educational Psychology, 77, 229-243. http://dx.doi.org/10.1348/000709905X90344

Koustelios, A., Karabatzaki, D., \& Kouisteliou, I. (2004). Autonomy and job satisfaction for a sample of Greek teachers. Psychological Reports, 95, 883-886. http://dx.doi.org/10.2466/pr0.95.3.883-886

Kristof, A. L. (1996). Person-organization fit: An integrative review of its conceptualizations, measurement and implications. Personnel Psychology, 49, 1-49. http://dx.doi.org/10.1111/j.1744-6570.1996.tb01790.x

Kyriacou, C. (2001). Teacher stress: Directions for future research. Educational Review, 53, 27-35. http://dx.doi.org/10.1080/00131910120033628

Lee, R. T., \& Ashforth, B. E. (1996). A meta-analytic examination of the correlates of the three dimensions of job burnout. Journal of Applied Psychology, 81, 123-133. http://dx.doi.org/10.1037/0021-9010.81.2.123

Leung, D. Y. P., \& Lee, W. W. S. (2006). Predicting intention to quit among Chinese teachers: differential predictability of the component of burnout. Anxiety, Stress, \& Coping, 19, 129-141. http://dx.doi.org/10.1080/10615800600565476

Lindqvist, P., \& Nordänger, U. K. (2006). Who dares to disconnect in the age of uncertainty? Teachers' recesses and 'off-the-clock' work. Teachers and Teaching. Theory and practice, 12, 623-637. http://dx.doi.org/10.1080/13540600601029637

Maslach, C., \& Jackson, S. E. (1981). Maslach Burnout Inventory Manual. Mountain View, California: CPP, Inc.

Maslach, C., Jackson, S. E., \& Leiter, M. P. (1996). Maslach Burnout Inventory Manual (3rd ed.). Mountain View, California: CPP, Inc.

McDonald, D. (1999). Teacher attrition: A review of literature. Teaching and Teacher Education, 15, 835-848. http://dx.doi.org/10.1016/S0742-051X(99)00031-1

Mtika, P., \& Gates, P. (2011). What do secondary trainee teachers say about teaching as a profession of their "choice" in Malawi? Teaching and Teacher Education, 27, 424-433. http://dx.doi.org/10.1016/j.tate.2010.09.012

Neves de Jesus, S., \& Lens, W. (2005). An integrated model for the study of teacher motivation. Applied Psychology, 54, 119-134. http://dx.doi.org/10.1111/j.1464-597.2005.00199.x

Otto, R. (1986). Teachers under stress: Health Hazards in a Work Role and Modes of Response. Melbourne: Hill of Content.

Peeters, M. A. G., \& Rutte, C. G. (2005). Time management behaviour as a moderator for the job demand-control interaction. Journal of Occupational Health Psychology, 10, 64-75. http://dx.doi.org/10.1037/1076-8998.10.1.64

Pithers, R. T., \& Soden, R. (1998). Scottish and Australian teacher stress and strain: A comparative study. British Journal of Educational Psychology, 68, 269-279. http://dx.doi.org/10.1111/j.2044-8279.1998.tb01289.x

Rinke, C. (2007). Understanding teachers' careers: Linking professional life to professional path. Educational Research Review, 3, 1-13. http://dx.doi.org/10.1016/j.edurev.2007.10.001

Sahlberg, P. (2010). Rethinking accountability in a knowledge society. Journal of Educational Change, 11, 45-61. http://dx.doi.org/10.1007/s10833-008-9098-2

Schaufeli, W. B., \& Salanova, M. (2007). Efficacy or inefficacy, that's the question: Burnout and work engagement, and their relationships with efficacy beliefs. Anxiety, Stress, \& Coping. An International Journal, 20, 177-196. http://dx.doi.org/10.1080/10615800701217878 
Scheopner, A. J. (2010). Irreconciable differences: Teacher attrition in public and catholic schools. Educational Research Review, 5, 261-277. http://dx.doi.org/10.1016/j.edurev.2010.03.001

Scott, C., Stone, B., \& Dinham, S. (2001). I love teaching but...International patterns of teaching discontent. Education Policy Analysis Archives, 9(28), 1-18. Retrieved from http://epaa.asu.edu/epaa/v9n28.html

Skaalvik, E. M., \& Skaalvik, S. (2009). Does school context matter? Relations with teacher burnout and job satisfaction. Teacher and Teacher Education, 25, 518-524. http://dx.doi.org/10.1016/j.tate.2008.12.006

Skaalvik, E. M., \& Skaalvik, S. (2010). Teacher self-efficacy and teacher burnout: A study of relations. Teacher and Teacher Education, 26, 1059-1069. http://dx.doi.org/10.1016/j.tate.2008.12.006

Skaalvik, E. M., \& Skaalvik, S. (2011a). Teacher job satisfaction and motivation to leave the teaching profession: Relations with school context, feeling of belonging, and emotional exhaustion. Teaching and Teacher Education, 27, 1029-1038. http://dx.doi.org/10.1016/j.tate.2009.11.001

Skaalvik, E. M., \& Skaalvik, S. (2011b). Teachers' feeling of belonging, echaustion, and job satisfaction: The role of school goal structure and value consonance. Anxiety, Stress, \& Coping, 24, 369-385. http://dx.doi.org/10.1080/10615806.2010.544300

Skaalvik, E. M., \& Skaalvik, S. (2014). Teacher self-efficacy and perceived autonomy: Relations with teacher engagement, job satisfaction, and emotional exhaustion. Psychological Reports, 114, 68-77. http://dx.doi.org/10.2466/14.02.PRO.114k14x0

Smithers, A., \& Robinson, P. (2008). Good teacher training guide. Buckingham: CEER.

Stoeber, J., \& Rennert, D. (2008). Perfectionism in school teachers: Relations with stress appraisals, coping styles, and burnout. Anxiety, Stress, \& Coping. An International Journal, 21, 37-53. http://dx.doi.org/10.1080/10615800701742461

Tang, C. S-K., Au, W-T., Schwarzer, R., \& Schmitz, G. (2001). Mental health outcomes of job stress among Chinese teachers: Role of stress resource factors and burnout. Journal of Organizational Behavior, 22, 887-901. http://dx.doi.org/10.1002/job.120

Watt, H. M. G., \& Richardson, P. W. (2008). Motivations, perceptions, and aspirations concerning teaching as a career for different types of beginning teachers. Learning and Instruction, 18, 408-428. http://dx.doi.org/10.1016/j.learninstruc.2008.06.002

Weiss, E. M. (1999). Perceived workplace conditions and first-year teachers' morale, career choice commitment, and planned retention: A secondary analysis. Teaching and Teacher Education, 27, 1029-1038. http://dx.doi.org/10.1016/S0742-051X(99)00040-2

Younger, M., Brindley, S., Pedder, D., \& Hagger, H. (2004). Sterting points: Student teachers' reasons for becoming teachers and their preconceptions of what this will mean. European Journal of Teacher Education, 27, 245-264. http://dx.doi.org/10.1080/0261976042000290787

Zembylas, M., \& Papanastasiou, E. (2006). Sources of teacher job satisfaction and dissatisfaction in Cyprus. Compare: A journal of Comparative and International Education, 36, 229-247. http://dx.doi.org/10.1080/03057920600741289

\section{Copyrights}

Copyright for this article is retained by the author(s), with first publication rights granted to the journal.

This is an open-access article distributed under the terms and conditions of the Creative Commons Attribution license (http://creativecommons.org/licenses/by/3.0/). 